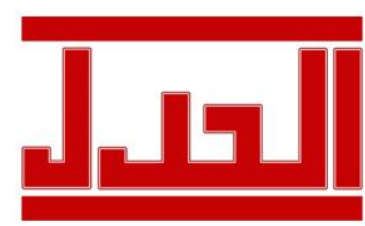

ISSN: $1979-4940$

E-ISSN: 2477-0124
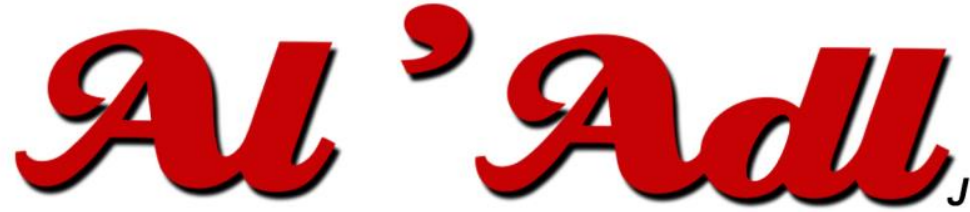

Jurnal Hukum

Editorial Office: Faculty of Law, Islamic University Of Kalimantan,

Jalan Adhyaksa No. 2 Kayutangi Banjarmasin, Kalimantan Selatan, Indonesia (70123)

Email: al_adl@uniska-bjm.ac.id

Web: http://ojs.uniska-bjm.ac.id

\section{Pemecahan Berkas Perkara Dan Relevansinya Dengan Asas Peradilan Cepat Dalam Perspektif Keadilan}

\author{
Sabirin \\ Universitas Islam Kalimantan Muhammad Arsyad Al Banjari \\ Jl. Adyaksa No. 2 Kayu Tangi Banjarmasin 70123 \\ Email: poruniskamab@gmail.com
}

$\begin{array}{ll}\text { Submitted } & : 2021 \\ \text { Revised } & : 2021 \\ \text { Accepted } & : 2021 \\ \text { Published } & : 2021\end{array}$

\begin{abstract}
The purpose of this research is to obtain an overview of the case criteria (splitsing) as an effort to facilitate the evidentiary process, obtain a description of the criteria for the application of case file separation and to find out the effect of splitting case files on the ease of the evidentiary process in court. The type of research used in this legal research is normative legal research that is prescriptive by using the Statute approach and the conceptual approach. From the results of the research conducted, it can be concluded that: First, the juridical implications of solving cases are to speed up and simplify the process of proof in the settlement of criminal cases. Second, the aspect of justice in the arrangement of splitting case files (splitsing) at the prosecution stage, namely as legal certainty for the defendant in seeking justice in the process of resolving criminal cases
\end{abstract}

Keywords : Solving Case Files; Fast Judicial Principles; Justice.

\section{Abstrak}

Tujuan dari penelitian ini adalah untuk memperoleh gambaran tentang Kriteria-kriteria perkara (splitsing) sebagai upaya mempemudah proses pembuktian, memperoleh deskripsi mengenai kriteria-kriteria penerapan pemisahan berkas perkara dan untuk mengetahui akibat pemecahan berkas perkara terhadap kemudahan dalam proses pembuktian di pengadilan. Jenis penelitian yang digunakan dalam penelitian hukum ini adalah penelitian hukum normatif yang bersifat preskriptif dengan menggunakan pendekatan Perundang-undangan (Statute approach) dan pendekatan konseptual (Conceptual Approach). dari hasil penelitian yang dilakukan dapat disimpulkan bahwa : Pertama, Implikasi yuridis pemecahan perkara yaitu mempercepat dan mempermudah proses pembuktian dalam penyelesaian perkara pidana. Kedua, Aspek keadilan pengaturan pemecahan berkas perkara (splitsing) pada tahap penuntutan yaitu sebagai kepastian hukum bagi terdakwa dalam mencari keadilan dalam proses penyelesaian perkara pidana.

Kata Kunci : Pemecahan Berkas Perkara, Asas Peradilan Cepat, Keadilan. 
Menurut sistem peradilan pidana untuk perkara yang sudah dilakukan penyidikan, diajukan ke kejaksaan. Fungsi kejaksaan adalah untuk menyaring berkas yang layak nantinya akan diajukan ke pengadilan, pengertian dari berkas yang layak tersebut adalah berkas yang nantinya dapat dijadikan dasar penetapan tersangka oleh penuntut umum yaitu sudah dicantumkannya secara lengkap syarat formil dan syarat materiilnya. Jaksa penuntut umum ditugaskan meneruskan perkara yang diterima dari kepolisisan atau instansi lain untuk mendapatkan penyelesaian menurut hukum. ${ }^{1}$

Jaksa sebagai penuntut umum diberi tugas menuntut seorang terdakwa di sidang pengadilan dan melaksanakan putusan serta penetapan hakim. Artinya, jaksa itu memiliki kekuasaan menetapkan apakah akan menuntut atau tidak menuntut hampir segala perkara pidana. ${ }^{2}$ Aparat penegak hukum menangani berbagai bentuk tindak pidana diantaranya, yaitu delik percobaan (poging/attempt), delik perbarengan tindak pidana (concursus), dan delik penyertaan (deelneming).

Konsekuensi yang akan timbul dari delik penyertaan adalah pengenaan pasal berbeda yang dijatuhkan pada masing-masing terdakwa berdasarkan peran serta unsur-unsur tindak pidana yang dilakukan. Semua bentuk penyertaan, turut serta atau terlibatnya orang-orang baik secara fisik maupun psikis dalam masing-masing perbuatan pidana tersebut berbeda. Setiap pelaku juga terdapat perbedaan sikap batin sehingga sanksi-sanksi dan konsekuensinya pun berbeda.

Setiap tindak pidana wajib untuk dibuktikan, dalam pasal 184 Ayat (1) KUHAP terdapat lima alat bukti yang sah dijadikan dasar terhadap pembuktian adannya suatu tindak pidana. Pembuktian perkara pidana membutuhkan alat bukti setidaknya 2 (dua) alat bukti untuk diajukan ketahap penuntutan terutama dalam kasus delik penyertaan karena alat bukti yang diajukan ketahap penuntutan dalam delik penyertaan masih banyak ditemui kekurangan karena delik penyertaan sendiri pasti dilakukan oleh lebih dari satu orang pelaku tindak pidana dan peran pelaku yang berbeda.

Tahap pembuktian di persidangan adalah hal penting yang bertujuan menentukan apakah suatu perbuatan termasuk perbuatan pidana atau bukan. Sistem pembuktian di Indonesia menitikberatkan pada hakim dalam mengambil keputusan mengenai bersalah atau tidaknya terdakwa sesuai alat bukti yang sah menurut undang-undang dan di tambah

\footnotetext{
${ }^{1}$ Bismar Siregar. 1983. Hukum Acara Pidana. Jakarta: Penerbit Bina Cipta. hlm. 86.

2 Andi Hamzah dan RM. Surachman. 1994. Kejahatan Narkotika dan Psikotropika. Jakarta: Sinar Grafika. hlm. 6.
} 
keyakinan hakim sendiri. ${ }^{3}$ Jaksa penuntut umum bertugas membuktikan kesalahan masingmasing terdakwa dalam persidangan dan pemberkasan terdakwa pelaku tindak pidana (voeging) digabungkan, sehingga hal ini berpengaruh pula pada pasal yang didakwakan.

Pasal 2 Ayat (4) Undang-Undang Nomor 48 Tahun 2009 tentang Kekuasaan Kehakiman menyebutkan bahwa peradilan dilakukan dengan cepat, sederhana, dan biaya ringan. Asas ini bertujuan, bahwa penegakan hukum dilaksanakan untuk memberi perlindungan dan kepastian hukum bagi pencari keadilan yang menjalani proses peradilan. ${ }^{4}$ Pemecahan perkara pidana oleh Jaksa penuntut umum bertujuan memudahkan pembuktian, agar proses pembuktian dapat dipercepat, karena tersangka/terdakwa terlibat dalam perkara yang sama dan tidak ada saksi, dimana jika jadi terdakwa semua, maka tidak ada saksi. Urgensi pemecahan berkas perkara menjadi beberapa berkas yang berdiri sendiri adalah untuk menempatkan para terdakwa masing-masing menjadi saksi timbal balik di antara sesama mereka. ${ }^{5}$

Pasal 142 KUHAP memberi kewenangan kepada penuntut umum untuk melakukan pemisahan berkas perkara pidana pemisahan perkara pidana apabila dalam suatu berkas perkara tersebut terdapat kekurangan alat bukti dan kesaksian. Pasal 142 KUHAP "Dalam hal penuntut umum menerima satu berkas perkara yang memuat beberapa tindak pidana yang dilakukan oleh beberapa orang tersangka yang tidak termasuk dalam ketentuan Pasal 141, penuntut umum dapat melakukan penuntutan terhadap masing-masing terdakwa secara terpisah". Dan pasal 141 KUHAP "Penuntut umum dapat melakukan penggabungan perkara dan membuatnya dalam satu surat dakwaan, apabila pada waktu yang sama atau hampir bersamaan ia menerima beberapa berkas perkara dalam hal:

1. beberapa tindak pidana yang dilakukan oleh seorang yang sama dan kepentingan pemeriksaan tidak menjadikan halangan terhadap penggabungannya

2. beberapa tindak pidana yang bersangkut-paut satu dengan yang lain;

3. beberapa tindak pidana yang tidak bersangkut-paut satu dengan yang lain, akan tetapi yang satu dengan yang lain itu ada hubungannya, yang dalam hal ini penggabungan tersebut perlu bagi kepentingan pemeriksaan.

\footnotetext{
${ }^{3}$ Hari Sasangka, Lily Rosita, (2003), Hukum Pembuktian dalam Perkara Pidana, Bandung: Mandar Maju. hlm. 13.

${ }^{4}$ Andi Hamzah, (2014), Hukum Acara Pidana Indonesia, Jakarta: Sinar Grafika, hlm. 10.

${ }^{5}$ Cristian Rompas, (2016), "Pemecahan Perkara Pidana (Splitsing) Sebagai Upaya untuk Mempercepat Proses Pembuktian”, Lex Privatum, Volume IV, Nomor 2, hlm. 113.
} 
Permasalahannya adalah apakah Pemecahan Berkas Perkara merupakan pelaksanaan dari asas peradilan cepat dan apakah dilakukannya Pemecahan Berkas Perkara sudah sesuai dengan asas keadilan.

\section{RUMUSAN MASALAH}

Berdasarkan latar belakang masalah diatas, maka rumusan masalah yang ditawarkan dalam penelitian ini adalah:

1. Bagaimana Implikasi Yuridis Pemecahan Berkas Perkara (splitsing) Terhadap Peradilan Cepat?

2. Bagaimana Aspek Keadilan Dalam Peraturan Mengenai Pemecahan Berkas Perkara (splitsing)?

\section{METODE PENELITIAN}

Dalam pembuatan sebuah karya ilmiah terutama karya ilmiah penelitian hukum diharuskan menggunakan metode penelitian hukum. Ilmu hukum berusaha untuk menampilkan hukum secara integral sesuai dengan kebutuhan kajian ilmu hukum itu sendiri, sehingga metode penelitian dibutuhkan untuk memperoleh arah penelitian yang komprehensif. ${ }^{6}$ Jenis penelitian yang digunakan dalam penelitian hukum ini adalah penelitian hukum normatif yang bersifat preskriptif dengan menggunakan Pendekatan PerundangUndangan (Statute Approach) dan Pendekatan Konseptual (Conceptual Approach).

\section{PEMBAHASAN}

\section{Implikasi Yuridis Pemecahan Berkas Perkara (Splitsing)}

Menurut M. Yahya Harahap, alasan dilakukannya splitsing karena adanya faktor berupa pelaku yang lebih dari satu orang sehingga penuntut umum dapat melakukan splitsing sesuai dengan kepentingan penuntutannya, adapun ciri-cirinya sebagai berikut: ${ }^{7}$

1. Penuntut umum akan memisah berkas perkara menjadi beberapa berkas;

2. Adanya pemisahan berkas karena tersangka yang ada beberapa orang dan akan dibuatkan masing-masing dakwaan secara tersendiri;

\footnotetext{
${ }^{6}$ Yati Nurhayati, "Perdebatan Metode Normatif dengan Metode Empirik Dalam Penelitian Ilmu Hukum Ditinjau Dari Karakter, Fungsi dan Tujuan Ilmu Hukum”, Jurnal Al Adl, Volume 5 Nomor 10, 2013, hlm. 15.

${ }^{7}$ Ibid, hlm. 442 .
} 
3. Dalam proses pemeriksaan, masing-masing terdakwa yang berkas perkaranya telah dipisah maka akan dalam persidangan yang berbeda pula;

4. Pemecahan perkara sering dilakukan karena perkara tersebut kurang bukti dan kesaksian.

Ketentuan syarat dan karakteristik pemisahan berkas perkara (Splitsing) oleh Penuntut Umum (PU) tidak diatur secara rigid dalam peraturan perundang-undangan. Hanya diatur mengenai landasan kewenangan Penuntut Umum (PU) dalam melakukan pemisahan berkas perkara (Splitising). Pertimbangan penuntut umum dalam melakukan pemisahan berkas perkara (Splitsing), yaitu : ${ }^{8}$

1. Pertimbangan secara materiil yaitu terdapat beberapa tindak pidana yang melibatkan beberapa orang pelaku yang memiliki peran masing-masing yang mana tempus dan locusnya berbeda yang mana biasanya merupakan tindak pidana yang tidak sederhana.

2. Pertimbangan secara formil yaitu kurangnya alat bukti khususnya alat bukti keterangan saksi.

Undang-Undang Nomor 16 Tahun 2004 tentang Kejaksaan tidak menyebutkan secara tegas mengenai kewenangan penuntut umum melakukan splitsing, akan tetapi KUHAP mengatur kewenangan melakukan penggabungan (voeging) atau pemisahan (splitising). ${ }^{9}$ Pengertian pemisahan berkas perkara pidana, yaitu pemecahan perkara terjadi karena adanya satu berkas perkara yang memuat lebih dari satu tindak pidana dan juga pelaku yang terdiri lebih dari satu orang disertai tidak memenuhi adanya syarat dari penggabungan berkas perkara sehingga penuntut umum harus melakukan pemisahan berkas perkara pidana atau splitsing. ${ }^{10}$ Menurut M. Yahya Harahap yang dimaksud dengan berkas perkara yaitu sebuah hasil penyidikan berupa berita acara perkara dan lampiran lainnya. ${ }^{11}$ Definisi berkas perkara merupakan berkas yang berisikan berita acara, bukti atau lampiran mengenai suatu perkara guna diserahkan kepada penuntut umum.

Pertimbangan penuntut umum dalam melakukan pemisahan perkara berpedoman pada pasal 142 KUHAP yang mengatur mengenai pemecahan perkara (splitsing) dengan berpangkal dari 1 (satu) berkas perkara dari Penyidik, kemudian Jaksa Penuntut Umum

\footnotetext{
${ }^{8}$ Fadli Satrianto, (2015), Pemisahan Berkas Perkara (Splitsing) Dalam Perkara Pidana Ditinjau Dari Hukum Positif, Universitas Airlangga, hlm. 99.

${ }^{9}$ Ibid.

${ }^{10}$ Wirjono Prodjodikoro dalam Djoko Prakoso, (1988), Pemecahan Perkara Pidana (Splitsing).Yogyakarta: Liberty, hlm. 111.

${ }^{11}$ Yahya Harahap, (2000), Pembahasan Permasalahan dan Penerapan KUHAP Penyidikan dan Penuntutan, Edisi Kedua, Jakarta: Sinar Grafika, hlm. 356.
} 
membuat surat dakwaan terhadap tersangka atau terdakwa. Splitsing dilakukan sebelum penuntut umum melimpahkan berkas perkara ke Pengadilan Negeri.

Rumusan pasal 142 KUHAP menyebutkan syarat-syarat dalam hal bagaimanakah penuntut umum dapat melakukan pemisahan perkara: ${ }^{12}$

1. Penuntut Umum menerima 1 (satu) berkas perkara;

2. satu berkas perkara memuat beberapa tindak pidana;

3. beberapa tindak pidana itu dilakukan oleh beberapa orang tersangka dan yang tidak termasuk dalam ketentuan Pasal 141 KUHAP.

Penjelasan Pasal 142 KUHAP menyebutkan bahwa splitsing dilakukan dengan membuat berkas perkara baru, dimana para tersangka saling menjadi saksi, sehingga untuk itulah perlu dilakukan pemeriksaan baru, baik terhadap tersangka maupun saksi. Keempat syarat untuk dapat dilakukannya pemecahan perkara (splitsing) tersebut akan diuraikan dan dibahas satu persatu berikut ini :

1. Penuntut Umum menerima 1 (satu) berkas perkara.

Yang diterima oleh Penuntut Umum dari Penyidik hanyalah 1 (satu) berkas perkara saja. Dari 1 (satu) berkas ini kemudian akan dilakukan pemecahan perkara (splitsing) sehingga menjadi lebih daripada satu perkara saja.

2. Satu berkas perkara itu memuat beberapa tindak pidana.

Dalam 1 (satu) berkas perkara itu termuat beberapa tindak pidana. Dalam syarat ini dengan jelas disebut adanya beberapa tindak pidana, jadi lebih daripada satu tindak pidana, dalam satu berkas tersebut. Dengan demikian, jika dalam 1 (satu) berkas perkara itu hanya dimuat 1 (satu) tindak pidana saja, Penuntut Umum tidak dapat melakukan pemecahan perkara (splitsing) sekalipun pelakunya ada beberapa orang.

3. Beberapa tindak pidana itu dilakukan oleh beberapa orang tersangka.

Menurut syarat ini, beberapa tindak pidana yang dimuat dalam satu berkas perkara itu dilakukan oleh beberapa orang tersangka.

4. Hal yang tidak termasuk dalam ketentuan Pasal 141 KUHAP.

Pasal 141 KUHAP mengatur ketentuan penggabungan perkara atau beberapa terdakwa dalam satu surat dakwaan, salah satu kriteria perkara perlu dilakukan splitsing tercantum pada Pasal 142 KUHAP yang merupakan kebalikan dari Pasal 141 KUHAP yaitu

\footnotetext{
${ }^{12}$ Ignasius A. Tiolong, Veibe V.Sumilat, Harold Anis, (2018), "Wewenang Pemecahan Perkara (Splitsing) Oleh Penuntut Umum Menurut Pasal 142 Undang-Undang Nomor 8 Tahun 1981”, Lex Crimen, Volume VII, Nomor 6, hlm. 2.
} 
memberikan wewenang kepada penuntut umum untuk melakukan pemecahan berkas perkara dari satu berkas menjadi beberapa berkas perkara.

Dasar pemecahan berkas perkara disebabkan pelaku tindak pidana terdiri dari beberapa orang, sehingga pemecahan berkas perkara ini dapat terjadi pada beberapa perkara yang merupakan tindak pidana yang terdiri dari beberapa orang. Setelah dilakukan penyidikan terdapat kekurangan saksi atau saksi yang ada merupakan pelaku tindak pidana itu sendiri, supaya pelaku tindak pidana atau terdakwa tidak lepas dari pertanggungjawaban hukum pidana dan proses peradilan tetap berjalan maka apabila terdakwa terdiri dari beberapa orang, dan berdasarkan pemeriksaan awal dari penyidik penuntut umum ragu untuk meneruskan perkara ke pengadilan karena kekurangan bukti dan saksi, Jaksa penuntut umum dapat mengambil kebijakan yaitu dengan memecah berkas perkara menjadi beberapa berkas sesuai dengan jumlah terdakwa.

Kriteria splitsing tidak harus digunakan semuanya, tergantung pada jaksa penuntut umum yang memeriksa perkara tersebut dan apa yang menjadi dasar ia untuk melakukan pemisahan perkara. Adanya kriteria splitsing diharapkan untuk mempermudah dalam menganalisa perkara pidana bukan dalam penerapannya, sehingga penuntut umum harus tepat dalam menerapkan splitsing pada perkara pidana.

Faktor-faktor yang menjadi pertimbangan pemisahan suatu berkas perkara oleh Jaksa penuntut umum pada pra penuntutan. Pemeriksaan oleh penyidik yang belum selesai tetap menjadi wewenang penyidik. Apabila hasil penyidikan yang sudah diserahkan penyidik kepada penuntut umum perlu untuk dilakukan splitsing (pemisahan berkas perkara) maka penuntut umum akan mengembalikan berkas perkara pada penyidik, hal ini untuk penyidikan tambahan dan untuk itu penuntut umum harus memeberikan petunjuk-petunjuk yang diperlukan, jadi pemeriksaan tambahan ini berdasarkan petunjuk-petunjuk yang diberikan oleh penuntut umum.

Dari alasan-alasan yang menjadikan faktor suatu berkas displit maka dapat diketahui bahwa dampak dari penggunaan splitsing adalah dengan maksud untuk memperkuat upaya pembuktian suatu perkara pidana (delik penyertaan) karena pada perkara yang berkasnya displit hakim dapat mengetahui langsung tindak pidana yang dilakukan masing-masing terdakwa secara jelas sebab berkasnya telah berdiri sendiri. Lagipula akan makin mempercepat pembuktian karena berkasnya sudah dipisah maka jelas unsur tindak pidananya, siapa terdakwanya, dan apa peran terdakwanya. 
Sistem pembuktian yang dianut oleh KUHAP di Indonesia bahwa hakim dalam mengambil keputusan tentang salah atau tidaknya seorang terdakwa terikat oleh alat bukti yang ditentukan oleh Undang-undang dan keyakinan hakim sendiri. Alat bukti yang ditentukan oleh Undang-Undang tidak bisa ditambah dengan alat bukti lain, serta berdasakan alat bukti yang diajukan di persidangan seperti yang ditentukan oleh Undang-Undang belum bisa memaksa seorang hakim menyatakan terdakwa bersalah telah melakukan tindak pidana yangdidakwakan, pernyataan tersebut merupakan pengertian sistem pembuktian negatif.

Alat bukti yang paling penting adalah keterangan saksi namun keterangan saksi tidak dianggap keterangan apabila :

1. Saksi hanya satu (unnus testis nullustestis)

2. Keterangan saksi yang didapat dari saksi/orang lain (testimonium de auditu)

Penggunaan saksi mahkota sendiri dalam splitsing perkara penyertaan, jadi intinya urgensi jaksa penuntut umum memisah berkas perkara bukan semata-mata untuk menghadirkan saksi mahkota namun terdapat beberapa alasan. Terkadang adanya saksi mahkota juga untuk memenuhi permintaan hakim untuk menghadirkan saksi yang memenuhi kualifikasi sebagai saksi menurut Pasal 1 angka 26 KUHAP yaitu kualifikasi seorang saksi dihadirkan di persidangan adalah tentang suatu perkara pidanayang ia dengar, ia lihat, dan ia alami sendiri, dalam delik penyertaan hal tersebut kadang sulit didapatkan maka salah satu caranya dengan menggunakan saksi mahkota.

Hal yang dikhawatirkan dari penggunaan saksi mahkota adalah bahwa ketika terdakwa atau saksi mahkota tersebut tidak mau mengaku, memang saat menjadi ia disumpah namun jika saksi mahkota tersebut tidak mau mengaku/ saling menutupi pada saat pembuktian di persidangan maka akan memepersulit jaksa penuntut umum hal ini dapat berakibat putusan bebas pada terdakwa karena jaksa penuntut umum tidak berhasil membuktikan kesalahan terdakwa. Alasan untuk memisah berkas perkara juga bisa datang dari unsur tindak pidananya sama atau berbeda.

Setelah pembuktian keterangan saksi selesai baru alat bukti lainnya guna mendukung argumentasi jaksa penuntut umum. Apabila semua alat bukti dari jaksa penuntut umum telah selesai maka giliran terdakwa/penasehat hukum (dalam hal ini saksi yang diajukan adalah saksi a de charge/saksi yang menguntungkan terdakwa), sama seperti pembuktian oleh jaksa penuntut umum jika setelah keterangan saksi selesai barulah alat bukti lain untuk melengkapi argumentasi dari penasehat hukum. 
Pemeriksaan paling akhir yaitu pemeriksaan terdakwa. Dalam delik penyertaan jelaslah bahwa terdakwanya lebih dari satu maka apabila berkasnya berbentuk voeging para terdakwadiperiksa bersama-sama dalam suatu perkara, maka pemeriksaannya dilakukan satu persatu dan bergiliran, apabila terdapat ketidaksesuaian jawaban diantara para terdakwa maka hakim dapat melakukan pengecekan antara jawaban terdakwa yang satu dengan terdakwa lainnya. Namun pada perkara yang di-splitsing karena berkas sudah dipisah maka pemeriksaan sidangnya pun sendiri-sendiri maka dari itu terdakwa lain dapat diambil sebagai saksi mahkota pada kasus terdakwa yang disidangkan.

Dalam KUHAP Indonesia memang tidak mengatur mengenai saksi mahkota, namun ada pada yurisprudensi, diantaranya Putusan Mahkamah Agung Nomor: 1986/K/Pid/1989 tanggal 2 Maret 1990 dan Mahkamah Agung Republik Indonesia dengan putusan Nomor: 66/K/Kr/1967 beberapa yurisprudensi di Indonesia masih mengakui bahwa saksi mahkota sebagai alat bukti saksi. Akan tetapi dalam yurisprudensi tidak ada ketentuan dampak bagi terdakwa apabila menjadi saksi pengurangan masa pidana atau dalam bentuk lain hanya keterangannya tersebut apabila sesuai dapat dijadikan alat bukti, terkait dengan tuntutan yang diberikan jaksa bisa berdasarkan pada peran dan tindak pidana masing-masing terdakwa apabila salah satu lebih ringan tindak pidananya dan saat menjadi saksi mahkota ia memberi keterangan yang benar berdasarkan peri kemanusiaan dapat mejadi pertimbangan jaksa penuntut umum dalam menuntut disamping itu apabila dari pihak korban sudah memaafkan maka hal tersebut juga dapat menjadi pertimbangan jaksa penuntut umum.

Pembuktian perkara pidana merupakan tititk sentral di dalam pemeriksaan perkara di Pengadilan. Hal ini karena melalui tahapan pembuktian inilah terjadi suatu proses, cara perbuatan membuktikan untuk menunjukkan benar atau salahnya si terdakwa terhadap suatu perkara pidana di dalam sidang pengadilan. Pembuktian adalah kegiatan membuktikan, dimana membuktikan berarti memperlihatkan bukti-bukti yang ada, melakukan sesuatu sebagai kebenaran, melaksanakan, menandakan, menyaksikan dan meyakinkan. Dari pemahaman tentang arti pembuktian di sidang pengadilan, sesungguhnya kegiatan pembuktian dapat dibedakan menjadi 2 bagian:

1. Bagian kegiatan pengungkapan fakta

2. Bagian pekerjaan penganalisisan fakta yang sekaligus penganalisisan hukum.

Di dalam bagian pengungkapan fakta, alat-alat bukti diajukan ke muka sidang oleh Jaksa Penuntut Umum dan Penasehat Hukum atau atas kebijakan Majelis Hakim untuk diperiksa kebenarannya. Proses pembuktian bagian pertama ini merupakan pengungkapan 
fakta saat persidangan, pembuktian yang pertama akan berakhir pada saat ketua majelis memang menyatakan pemeriksaan terhadap perkara dinyatakan selesai (Pasal 182 Ayat (1) huruf a KUHAP), maka selanjutnya jaksa penuntut umum, penasehat hukum, dan majelis hakim melakukan penganalisisaan fakta juga hukum. Oleh jaksa penuntut umum pembuktian pada bagian pekerjaan penganalisaan fakta yang sekaligus penganalisaan hukum maka dilakukannya dituangkan dalam bentuk surat tuntutannya (requisitoir). Bagi penasehat hukum pembuktiannya dilakukan dalam nota pembelaan (pledoi), dan pembuktian menurut jaksa penuntut umum dan penasehat hukum akan dibahas dalam musyawarah Majelis Hakim dan dimuat dalam putusan akhir (vonnis) yang dibuatnya.

Salah satu asas menurut Pasal 2 Ayat (4) Undang-Undang Nomor 48 Tahun 2009 tentang Kekuasaan Kehakiman yaitu peradilan dilakukan dengan sederhana, cepat, dan biaya ringan. Asas ini menghendaki agar pelaksanaan penegakan hukum di Indonesia berpedoman kepada Asas Peradilan Cepat, Sederhana, dan Biaya Ringan untuk memberi perlindungan dan kepastian hukum bagi pencari keadilan yang menjalani proses peradilan. ${ }^{13}$

Pasal 2 Ayat (4) Undang-Undang Nomor 48 Tahun 2009 tentang Kekuasaan Kehakiman, menjelaskan bahwa yang dimaksud:

a. Peradilan cepat, penanganan perkara dapat diselesaikan dalam waktu yang singkat, tidak perlu memakan waktu yang lama, sehingga dapat mengurangi ketidakpastian hukum dalam penyelesaian perkara.

b. Sederhana adalah pemeriksaan dan penyelesaian perkara dilakukan dengan cara efesien dan efektif.

c. Biaya ringan adalah biaya perkara yang dapat dijangkau oleh masyarakat.

d. Asas sederhana, cepat, dan biaya ringan dalam pemeriksaan dan penyelesaian perkara di pengadilan tidak mengesampingkan ketelitian dan kecermatan dalam mencari kebenaran dan keadilan.

Asas peradilan cepat harus dijalankan dalam setiap proses peradilan, apabila dihubungkan dengan perkara yang di-splitsing oleh Jaksa penuntut umum adalah untuk menghindarkan prose peradilan yang berlarut-larut dan terlalu lama sehingga tercapainya kepastian hukum. Sedangkan splitsing berlaku untuk beberapa tindak pidana yang dilakukan oleh beberapa orang tersangka dan bukannya pada satu tindak pidana yang dilakukan oleh beberapa orang tersangka. Hal ini berimplikasi untuk mempercepat dan mempermudah proses pembuktian dalam penyelesaian perkara pidana.

\footnotetext{
${ }^{13}$ Andi Hamzah, (2014), Hukum Acara Pidana Indonesia, Jakarta: Sinar Grafika, hlm. 10
} 


\section{Aspek Keadilan Dalam Peraturan Mengenai Pemecahan Berkas Perkara (Splitsing)}

Pasal 142 KUHAP ini mengatur mengenai pemecahan perkara (splitsing) di mana dengan berpangkal dari 1 (satu) berkas perkara dengan beberapa tersangka yang diterima dari Penyidik, kemudian Jaksa Penuntut Umum membuat beberapa surat dakwaan terhadap masing-masing tersangka/terdakwa.

Ditinjau dari sudut kepentingan penuntutan, dilakukannya pemecahan perkara (splitsing), di mana saksi di suatu perkara menjadi terdakwa di perkara lainnya, merupakan suatu teknik yang mendukung atau bermanfaat bagi kepentingan penuntutan. Apa yang dimaksudkan dengan kepentingan penuntutan, dapat dipahami dengan melihat apa yang dimaksudkan dengan penuntutan sehingga darinya dapat diketahui pula apa yang merupakan tujuan dari tahap penuntutan. Pada Pasal 1 butir 7 KUHAP diberikan definisi bahwa Penuntutan adalah tindakan penuntut umum untuk melimpahkan perkara pidana ke pengadilan negeri yang berwenang dalam hal dan menurut cara yang diatur dalam undangundang ini dengan permintaan supaya diperiksa dan diputus oleh hakim di sidang pengadilan. Jadi, tujuan dari penuntutan adalah:

1. Agar Penuntut Umum dapat melakukan penuntutan, yaitu melimpahkan perkara pidana ke pengadilan negeri yang berwenang;

2. Agar perkara diputus oleh Hakim di sidang pengadilan sesuai dengan apa yang dimaksudkan dalam isi penuntutan. Dengan kata lain, agar terdakwa dapat dinyatakan bersalah dan dipidana oleh Hakim.

Kepentingan penuntutan adalah agar Penuntut Umum dapat melimpahkan perkara ke pengadilan dan pada akhirnya orang yang dituntut itu dapat dinyatakan bersalah dan dijatuhi pidana oleh pengadilan. Penuntut Umum melakukan pemecahan berkas perkara (splitsing) adalah dengan maksud agar Penuntut Umum memiliki cukup bukti, dalam hal ini saksi, untuk membuktikan dakwaannya dalam suatu perkara. Jadi, agar Penuntut Umum dapat melakukan penuntutan dan dakwaan yang bersangkutan kemungkinan besar akan berhasil dibuktikan di depan sidang pengadilan. Oleh karenanya, sebagaimana dikemukakan sebelumnya, ditinjau dari sudut kepentingan penuntutan, dilakukannya pemecahan berkas perkara, yaitu di mana saksi di suatu perkara menjadi terdakwa di perkara lainnya, merupakan suatu teknik penuntutan yang mendukung atau bermanfaat untuk kepentingan penuntutan. Tetapi, bagaimana halnya jika pemecahan perkara tersebut dilihat dari sudut perlindungan Hak Asasi Manusia tersangka/terdakwa? Sebagaimana diketahui, sebagai pertimbangan utama 
diadakannya KUHAP menggantikan HIR justru untuk memberikan pengakuan dan perlindungan yang lebih baik terhadap Hak Asasi Manusia.

Pemecahan perkara yang mengakibatkan seorang saksi di suatu perkara menjadi tersangka di perkara lainnya, sedangkan perkara itu ada kaitannya satu dengan yang lain, menimbulkan benturan antara kepentingan penuntutan dengan Hak Asasi Manusia tersangka/terdakwa. Kepentingan penuntutan, sebagaimana dikemukakan di atas, membenarkan dilakukannya hal sedemikian. Tetapi pertimbangan pengakuan dan perlindungan Hak Asasi Manusia (human rights) menghendaki dilakukannya kajian yang lebih mendalam mengenai pokok tersebut.

Pasal 137 KUHAP menyatakan bahwa, "penuntut umum berwenang melakukan penuntutan terhadap siapapun yang didakwa melakukan suatu tindak pidana dalam daerah hukumnya dengan melimpahkan perkara ke pengadilan yang berwenang mengadili" pada pasal tersebut menyatakan bahwa kewenangan untuk menuntut dan tidak menuntut seseorang ada pada penuntut umum. Selanjutnya pada Pasal 140 Ayat (1) KUHAP menegaskan bahwa "Dalam hal penuntut umum berpendapat bahwa dari hasil penyidikan dapat dilakukan penuntutan, ia dalam waktu secepatnya membuat surat dakwaan" karena kewenangan menuntut ada pada penuntut umum maka penuntut umum juga memiliki kewajiban atau konsekuensi untuk membuat surat dakwaan bagi seseorang yang berdasarkan hasil penyidikan terbukti melakukan suatu tindak pidana. Sebagai dasar, Pasal 14 KUHAP juga menyebutkan beberapa wewenang yang dimiliki penuntut umum yang berhubungan dengan surat dakwaan terdapat pada Pasal 14 huruf d KUHAP ditulis secara tegas bahwa jaksa penuntut umum berwenang membuat dakwaan.

Sesuai dengan rumusan Pasal 143 Ayat (2) KUHAP maka selain berwenang membuat dakwaan penuntut umum atau jaksa harus memeperhatikan syarat-syarat surat dakwaannya juga. Jaksa Penuntut Umum pastinya mengetahui, memahami membuat atau merumuskan surat dakwaan, biasanya jaksa membuat dakwaan tunggal apabila pelaku tindak pidana atau terdakwa hanya melanggar suatu ketentuan pidana. Melalui dakwaan pula, bertujuan memberikan suatu pilihan kepada hakim dalam pengadilan untuk menentukan dakwaan mana yang tepat yang dipertanggung jawabkan kepada terdakwa karena tindak pidana yang dilakukannya.Biasanya dalam dakwaan memuat suatu tuntutan pidana mulai dari yang terberat sampai yang paling ringan, yang semuanya saling berkaitan atau bersinggungan. Namun juga terdapat suatu dakwaan yang memuat beberapa tindak pidana yang dilakukan seseorang, namun tindak pidana tersebut masing-masing saling terpisah biasanya juga 
terdapat suatu dakwaan dimana menggabungkan seluruh tuntutan yang didakwakan kepada terdakwa yang melakukan satu atau lebih suatu tindak pidana baik itu tindak pidana khusus atau umum atau juga terhadap suatu kewenangan relatif bahkan kewenangan absolut dalam suatu peradilan.

Pemisahan berkas perkara (splitsing) ialah memecah satu berkas perkara menjadi dua atau lebih berkas perkara. Undang-undang dan praktik hukum memberi kemungkinan memisahkan perkara atau beberapa orang dalam lebih satu berkas perkara. Aturan splitsing termaktub dalam Pasal 142 KUHAP sebagaimana pengecualian dari aturan Pasal 141 KUHAP terkait tentang penggabungan perkara (voeging). Pasal 141 KUHAP menyatakan bahwa:

Pasal 141

Penuntut Umum dapat melakukan penggabungan perkara dan membuatnya dalam satu surat dakwaan, apabila pada waktu yang sama atau hampir bersamaan ia menerima beberapa berkas perkara dalam hal:

1. Beberapa tindak pidana yang dilakukan oleh seseorang yang sama dan kepentingan pemeriksaan tidak menjadikan halangan terhadap penggabungannya;

2. Beberapa tindak pidana yang bersangkut paut satu dengan yang lain;

3. Beberapa tindak pidana yang tidak bersangkut paut satu dengan yang lain, akan tetapi yang satu dengan yang lain itu ada hubungannya, yang dalam hal ini penggabungan tersebut perlu bagi kepentingan bersama.

Pasal 142 KUHAP

Dalam hal Penuntut Umum menerima satu berkas perkara yang memuat beberapa tindak pidana yang dilakukan oleh beberapa orang tersangka yang tidak termasuk dalam ketentuan Pasal 141, Penuntut Umum dapat melakukan penuntutan terhadap masing-masing terdakwa secara terpisah.

Pemecahan penuntutan perkara (splitsing) seperti yang dimaksud dalam ketentuan Pasal 142 KUHAP, biasanya splitsing dilakukan dengan membuat berkas perkara baru. Dalam hal yang demikian perlu dilakukan pemeriksaan baru, baik terhadap terdakwa maupun saksi. Dengan adanya pemeriksaan baru terhadap terdakwa maupun saksi, maka baik terdakwa maupun saksi harus dibuatkan surat tuntutan.

Penuntut umum dalam merumuskan surat dakwaan haruslah sejalan dengan hasil pemeriksaan penyidikan. Rumusan surat dakwaan yang menyimpang dari hasil pemeriksaan 
penyidikan merupakan surat dakwaan yang palsu dan tidak benar. Surat dakwaan yang demikian tidak dapat dipergunakan penuntut umum terhadap terdakwa.

Pada dasarnya pemecahan berkas perkara menjadi penting karena dapat disebabkan faktor pelaku tindak pidana terdiri dari beberapa orang. Pemecahan berkas perkara ini dapat terjadi pada beberapa perkara yang merupakan tindak pidana yang terdiri dari beberapa orang, sedangkan setelah dilakukan penyidikan terdapat kekurangan saksi atau saksi yang ada merupakan pelaku tindak pidana itu sendiri, misalnya kasus pemerkosaan, ataupun korupsi. Agar pelaku tindak pidana atau terdakwa tidak terlepas dari pertanggungjawaban hukum pidana dan proses peradilan tetap berjalan maka apabila terdakwa terdiri dari beberapa orang, dan berdasarkan pemeriksaan awal dari penyidik penuntut umum ragu untuk meneruskan perkara ke pengadilan karena kekurangan bukti dan saksi, maka penuntut umum dapat menempuh kebijaksanaan lain yaitu dengan memecah berkas perkara menjadi beberapa berkas sesuai dengan jumlah terdakwa.

Dalam hal terdakwa diajukan sebagai saksi mahkota tentunya terdakwa tidak dapat memberikan keterangan secara bebas karena terikat dengan sumpah. Kosekuensi terhadap pelanggaran sumpah ini adalah ia bisa diancam melanggar Pasal 242 KUHP tentang sumpah palsu dan keterangan palsu. Adanya keterikatan dengan sumpah tersebut tentunya akan menimbulkan tekanan psikologis bagi terdakwa karena ia tidak dapat menggunakan haknya untuk ingkar atau berbohong.

Keabsahan keterangan saksi menurut hukum harus memenuhi beberapa kriteria sebagaimana ditentukan dalam Pasal 1 butir 26 KUHAP sebagai berikut :

1. Saksi harus memberikan sumpah atau janji sebelum memberikan keterangan;

2. Keterangan saksi harus mengenai peristiwa pidana yang saksi tersebut melihat, mendengar dan mengalami sendiri dengan menyebutkan alasan pengetahuannya. Dengan demikian keterangan saksi yang diperoleh secara testimonium de auditu (keterangan yang diperoleh dari orang lain) tidak mempunyai nilai pembuktian

3. Keterangan saksi harus diberikan di muka sidang pengadilan (kecuali yang ditentukan lain pada Pasal 162 KUHAP

4. Keterangan seorang saksi saja tidak cukup untuk membuktikan kesalahan terdakwa (unustestis nullus testis);

5. Jika ada beberapa saksi terhadap beberapa perbuatan, kesaksian itu sah menjadi alat bukti dan apabila saksi satu dengan yang lain terhadap perbuatan itu bersangkut paut dan bersesuaian, untuk menilainya diserahkan kepada hakim. 
Selanjutnya keterangan saksi harus memenuhi syarat, baik secara formil maupun materil. Adapun syarat formil saksi adalah sebagai berikut :

1. Namanya sudah ada dalam surat pelimpahan berkas perkara (Pasal 160 Ayat (1) huruf (c) KUHAP;

2. Diminta oleh terdakwa atau penasehat hukum, atau penuntut umum (Pasal 160 Ayat (1) huruf (c) KUHAP;

3. Dihadapkan kepada hakim, baik oleh penuntut umum, terdakwa atau penasihat hukum (Pasal 165 Ayat (4) KUHAP;

4. Harus dipanggil secara resmi melalui surat yang sudah diterima 3 hari sebelum sidang pengadilan (Pasal 146 Ayat (2) KUHAP.

Sedangkan syarat materil untuk menjadi saksi adalah sebagai berikut :

1. Tidak berhubungan keluarga sedarah, atau semenda garis lurus keatas atau ke bawah sampai derajat ketiga (Pasal 168 huruf a KUHAP);

2. Tidak berhubungan saudara baik dari pihak ayah maupun ibu sampai derajat ketiga (Pasal 168 huruf b KUHAP);

3. Tidak mempunyai hubungan suami istri meskipun sudah bercerai (Pasal 168 huruf c KUHAP);

4. Dewasa, berumur lebih dari 15 tahun (Pasal 171 huruf a KUHAP);

5. Tidak sakit ingatan atau sakit jiwa (Pasal 171 huruf b KUHAP).

Ditinjau dari segi nilai dan kekuatan pembuktian keterangan saksi, agar mempunyai nilai dan kekuatan pembuktian, perlu diperhatikan ketentuan yang harus dipenuhi oleh seorang saksi.Artinya agar keterangan seorang saksi dapat dianggap sah sebagai alat bukti yang mempunyai kekuatan pembuktian, harus dipenuhi ketentuan undang-undang (KUHAP).

Pertama, menurut Pasal 160 Ayat (3) sebelum saksi memberikan keterangan terlebih dahulu "wajib mengucapkan" sumpah atau janji. Sumpah atau janji tersebut dilakukan menurut cara agamanya masing-masing dengan lafal sumpah atau janji bahwa saksi akan memberikan keterangan yang sebenar-benarnya dan tiada lain daripada yang sebenarnya. Sumpah pada prinsipnya wajib diucapkan "sebelum" saksi memberikan keterangan. Namun ketentuan Pasal 160 Ayat (4) memberi kemungkinan untuk mengucapkan sumpah atau janji "sesudah" saksi memberikan keterangan.

Kedua, keterangan saksi yang bernilai sebagai bukti adalah keterangan yang sesuai dengan ketentuan Pasal 1 angka 27 KUHAP, yaitu keterangan yang saksi lihat sendiri, saksi dengar sendiri, saksi alami sendiri serta menyebut alasan dari pengetahuannya itu. Menurut 
ketentuan Pasal 185 KUHAP yang dihubungkan dengan penegasan pasal 1 angka 27 KUHAP maka dapat diketahui bahwa :

1. Setiap keterangan saksi diluar apa yangdidengarnya sendiri dalam peristiwa pidana yang terjadi atau diluar yang dilihat atau dialaminya dalam peristiwa pidana yang terjadi, keterangan yang diberikan diluar pengadilan, penglihatan atau pengalaman sendiri mengenai suatu peristiwa pidana yang terjadi, tidak dapat dijadikan dan dinilai sebagai alat bukti. Keterangan semacam itutidak mempunyai kekuatan nilai pembuktian.

2. Testimonium de auditu atau keterangan saksi yang ia peroleh sebagai hasil pendengaran dari orang lain, "tidak mempunyai nilai sebagai alat bukti”. Keterangan saksi di sidang pengadilan berupa keterangan ulangan dari apa yang didengarnya dari orang lain, tidak dapat dianggap sebagai alat bukti.

3. Pendapat atau rekaan yang saksi peroleh dari hasil pemikiran, bukan merupakan keterangan saksi. Penegasan ini sesuai dengan ketentuan Pasal 185 Ayat (5) KUHAP. Hal ini sejalan pula dengan Putusan Mahkamah Agung tanggal 15 Maret 1984 Reg. Nomor: 20PK/Pid/1983. Dalam putusan ini ditegaskan bahwa "orang tua terdakwa, polisi, dan jaksa hanya menduga, tetapi dalam dugaan itu semua hanya merupakan kesimpulan sendiri-sendiri yang tidak didasarkan pada alat-alat bukti yang sah.

Ketiga, keterangan saksi harus diberikan di sidang pengadilan. Agar keterangan saksi bernilai sebagai alat bukti, maka keterangan itu harus "dinyatakan" di depan sidang pengadilan. Keterangan yang dinyatakan di luar sidang pengadilan (outside the court) bukan alat bukti, tidak dapat dipergunakan untuk membuktikan kesalahan terdakwa. Meskipun misalnya hakim, penuntut umum, terdakwa atau penasihat hukum ada mendengar keterangan seorangyang berhubungan dengan peristiwa pidana yang sedang diperiksa, dan keterangan itu mereka dengar di halaman kantor pengadilan atau disampaikan oleh seseorang kepada hakim di rumah tempat tinggalnya. Keterangan yang demikian tidak dapat dinilai sebagai alat bukti karena ia tidak dinyatakan di sidang pengadilan.

Keempat, keterangan seorang saksi saja dianggap tidak cukup. Hal ini sejalan dengan asas dalam hukum pembuktian bahwa unus testis nullus testis. Asas ini jika dihubungkan dengan ketentuan Pasal 185 Ayat (2) KUHAP maka sangat sesuai dimana diatur bahwa keterangan seorang saksi saja belum dapat dianggap sebagai alat bukti yang cukup untuk membuktikan kesalahan terdakwa. Ini berarti jika alat bukti yang dikemukakan penuntut umum hanya terdiri dari seorang saksi saja tanpa ditambah dengan keterangan saksi yang lain atau alat bukti yang lain, atau kesaksian tunggal, maka yang seperti ini tidak dapat dinilai 
sebagai alat bukti yang cukup untuk membuktikan kesalahan terdakwa sehubungan dengan tindak pidanayang didakwakan kepadanya.

Kelima,keterangan beberapa saksi yang berdiri sendiri. Keterangan saksi meskipun disampaikan oleh beberapa orang, melampaui batas minimum kuantitas saksi, tetapi jika keterangan mereka masing-masing berdiri sendiri maka tidak memiliki nilai pembuktian. Keterangan yang dibutuhkan adalah keterangan saksi yang satu dan lainnya saling bersesuaian atau saling berhubungan yang dapat mewujudkan suatu kebenaran akan adanya kejadian atau keadaan tertentu. Berapapun banyaknya saksi yang diperiksadan didengar keterangannya di sidang pengadilan, tetapi kesemuannya tidak bermanfaat untuk memenuhi syarat pembuktian jika keterangan mereka satu dan lain saling bertentangan atau saling tidak bersesuaian atau tidak ada hubungan satu sama lainnya.

Akumulasi positif dari kelima syarat tersebut secara simultan barulah dapat dipastikan bahwa keterangan saksi yang diajukan di depan sidang pengadilan memiliki nilai pembuktian yang diharapkan dapat membuktikan kesalahan terdakwa. Jika syarat-syarat tersebut tidak dipenuhi maka yang dapat dipastikan adalah keterangan saksi tersebut tidak memenuhi syarat pembuktian sehingga tidak memiliki nilai pembuktian. Jika tidak memiliki nilai pembuktian yang demikian maka sia-sialah pemeriksaan terhadap saksi dalam sidang pengadilan.

Kemudian yang terakhir perlu diketahui adalah tentang bagaimana cara menilai kebenaran keterangan saksi sehingga dapat dijadikan alat bukti yang memenuhi standar pembuktian yang seharusnya. Menurut ketentuan Pasal 185 Ayat (6) KUHAP maka tugas hakim yang menilai pembuktian haruslah sungguh-sungguh memperhatikan hal-hal sebagai berikut :

1. Persesuaian antara keterangan saksi. Saling persesuaian antara keterangan saksi harus jelas untuk penjabarannya dalam pertimbangan hakim, sedemikian rupa jelasnya diuraikan secara terperinci dan sistematis. Tidak boleh hanya diuraikan secara ngambang dan deskriptif saja, tetapi harus diurai secara jelas, rinci, runtut dan sistematis dalam uraian yang menghubungkan antara keterangan saksi yang satu dengan saksi lainnya, sehingga saling berhubungan atau bersesuaian, tidak saling bertentangan.

2. Persesuaian keterangan saksi dengan alat bukti lain. Jika penuntut umum mengajukan saksi dan alat-alat bukti lainnya seperti keterangan ahli, surat atau petunjuk, hakim dalam sidang maupun pertimbangannya, harus meneliti dengan sungguh-sungguh persesuaian maupun pertentangan antara keterangan saksi itu dengan alat bukti yang lain tersebut. 
3. Alasan saksi memberi keterangan tertentu. Dalam hal ini Hakim harus mencari alasan saksi, kenapa memberikan keterangan yang seperti itu. Tanpa mengetahui alasan saksi yang pasti, akan memberikan gambaran yang kabur bagi hakim tentang keadaan yang diterangkan saksi. Misalnya mengenai kepastian saksi melihat terdakwa, apakah pasti memang saksi benar-benar melihat terdakwa dari jarak yang wajar dapat dilihat dengan terang atau samar-samar atau bahkan tidak jelas atau kurang jelas, dan seterusnya.

Pandangan yang membenarkan pemeriksaan saksi mahkota antara lain tertuang dalam Putusan Mahkamah Agung Nomor 1986/K/Pid/1989 tanggal 21 Maret 1990. Alasan putusan tersebut adalah bahwa Undang-Undang tidak melarang jaksa penuntut umum mengajukan "saksi mahkota" dengan syarat dan kondisi tertentu bahwa saksi ini dalam kedudukannya sebagai terdakwa tidak termasuk dalam satu berkas perkara dengan terdakwa yang diberikan kesaksian. Jadi disini “penggunaan" saksi mahkota dibenarkan didasarkan pada prinsipprinsip tertentu:

1) dalam perkara penyertaan tindak pidana;

2) terdapat kekurangan alat bukti; dan

3) diperiksa dengan mekanisme pemisahan berkas perkara (splitsing).

Pandangan yang menolak pemeriksaan saksi mahkota antara lain didukung oleh Putusan mahkamah Agung Republik Indonesia Nomor: 1174/K/ Pid/ 1994 tanggal 3 Mei 1995, Putusan Mahkamah Agung Republik Indonesia Nomor: 1952/K/Pid/1994 tanggal 29 April 1995, Putusan Mahkamah Agung Nomor: 1590/K/Pid/1995 tanggal 3 Mei 1995, dan Putusan Mahkamah Agung Republik Indonesia Nomor: 1592 K/Pid 1995 tanggal 3 Mei 1995.

Saksi mahkota yang juga pelaku tindak pidana, diajukan sebagai terdakwa yang dakwaannya sama dengan terdakwa yang diberikan kesaksian. Saksi yang disumpah, harus berkata benar tentang apa yang ia lihat, ia dengar dan ia alami. Kalau tidak, ia dapat dipidana atas kesaksiannya. ${ }^{14}$

Dengan demikian keberadaan saksi mahkota di Indonesia, terutama dalam praktek peradilan pidana masih ditemukan, meskipun terdapat pandangan yang menyetujui atau menolak kehadiran dan pemeriksaan saksi mahkota. Bagi yang mendukung beralasan bahwa saksi mahkota masih diperlukan untuk kasus tertentu yang kurang alat buktinya, serta diajukan dalam berkas perkara yang berbeda dengan metode splitsing perkara oleh jaksa penuntut umum. Pandangan yang menolak pemeriksaan saksi mahkota didukung oleh alasan

${ }^{14}$ https://123dok.com/document/7q063p9q-kedudukan-sanksi-mahkota-dalam-sistem-pembuktian-hukumpidana.html, diakses pada tanggal 10 April 2021. 
bahwa bagaimanapun pemeriksaan saksi mahkota melanggar hak-hak asasi tersangka, serta perlunya fair trial dalam proses peradilan pidana sesuai dengan prinsip due process of law.

Oleh karena itu, pada hakikatnya kesaksian yang diberikan saksi mahkota tersebut disamakan dengan pengakuan yang didapat dengan menggunakan kekerasan dalam hal ini kekerasan psikis. Hal ini jelas bertentangan dengan prinsip-prinsip peradilan yang adil dan tidak memihak (fair trial) dan juga merupakan pelanggaran terhadap kaidah HAM sebagaimana dikenal dalam KUHAP maupun International Covenant on Civil and Political Rights (ICCPR).

Pada dasarnya, ketentuan Pasal 14 Ayat (3) huruf g ICCPR bertujuan untuk melarang paksaan dalam bentuk apapun. Selain itu, diamnya tersangka atau terdakwa tidak dapat digunakan sebagai bukti untuk menyatakan kesalahannya. Terdakwa tidak boleh dipersalahkan atas keterangannya. Kondisi ini, sangat tidak adil bagi terdakwa. Sementara, tujuan dari penegakan hukum, tidak hanya menegakan hukum, tetapi juga keadilan baik untuk korban maupun terdakwa. Apalagi, keterangan yang diberikan besar kemungkinan menunjukan kesalahan terdakwa dalam kasus tersebut.

Sesungguhnya konsep keadilan sangat sulit mencari tolak ukurnya karena adil bagi satu pihak belum tentu dirasakan oleh pihak lainnya. Kata keadilan berasal dari kata adil, yang berarti dapat diterima secara obyektif. ${ }^{15}$

Menurut Aristoteles, ada beberapa pengertian keadilan, antara lain yakni Keadilan berbasis persamaan, distributif, dan korektif. ${ }^{16}$

1. Keadilan berbasis persamaan, didasarkan atas prinsip bahwa hukum mengikat semua orang, sehingga keadilan yang hendak dicapai oleh hukum dipahami dalam konteks kesamaan. Kesamaan yang dimaksudkan disini terdiri dari atas kesamaan numerik dan kesamaan proporsional. Kesamaan numeric berprinsip kesamaan derajat atas setiap orang di hadapan hukum, sedangkan kesamaan proporsional adalah memberi kepada setiap orang apa yang sudah menjadi haknya.

2. Keadilan distributif, hal ini identik dengan keadilan proporsional, dimana keadilan distributif berpangkal pada pemberian hak sesuai dengan besar kecilnya jasa, sehingga dalam hal ini keadilan didasarkan pada persamaan, melainkan sesuai dengan porsinya masing-masing (proporsional).

\footnotetext{
${ }^{15}$ Satjipto Rahlmardjo, (1996), Ilmu Hukum, Bandung: PT. Citra Aditya Bakti, hlm. 19.

${ }^{16} \mathrm{http}$ ://id.wikipedia.org/wiki/Aristoteles/keadilan, diakses pada tanggal 10 April 2021.
} 
3. Keadilan korektif, pada dasarnya merupakan keadilan yang bertumpu pada pembetulan atas suatu kesalahan, misalnya apabila ada kesalahan orang yang menimbulkan kerugian bagi orang lain, maka orang yang mengakibatkan munculnya kerugian, harus memberikan ganti rugi (kompensasi) kepada pihak yang menerima kerugian untuk memulihkan keadaannya sebagai akibat dari kesalahan yang dilakukan.

Menurut L.J Van Apeldoorn mengatakan bahwa,"keadilan tidak boleh dipandang sama arti dengan persamarataan, keadilan bukan berarti bahwa tiap-tiap orang memperoleh bagian yang sama". ${ }^{17}$ Maksudnya keadilan menuntut tiap-tiap perkara harus ditimbang tersendiri, artinya adil bagi seseorang belum tentu adil bagi yang lainnya. Tujuan hukum adalah mengatur pergaulan hidup secara damai jika ia menuju peraturan yang adil, artinya peraturan dimana terdapat keseimbangan antara kepentingan-kepentingan yang dilindungi, dan setiap orang memperoleh sebanyak mungkin yang menjadi bagiannya.

Keadilan tidak boleh dipandang sama arti dengan persamarataan. Keadilan bukan berarti bahwa tiap-tiap orang memperoleh bagian yang sama. Jika hukum semata-mata menghendaki keadilan, jadi semata-mata mempunyai tujuan memberi tiap-tiap orang apa yang patut diterimanya, maka ia tak dapat membentuk peraturan-peraturan umum. Tertib hukum yang tak mempunyai peraturan umum, bertulis atau tidak bertulis adalah tidak mungkin. Tak adanya peraturan umum, berarti ketidaktentuan yang sungguh-sungguh, mengenai apa yang disebut adil atau tidak adil. Ketidaktentuan itu akan menyebabkan perselisihan. Jadi hukum harus menentukan peraturan umum, harus menyamaratakan. Keadilan melarang menyamaratakan; keadilan menuntut supaya tiap-tiap perkara harus ditimbang tersendiri makin banyak hukum memenuhi syarat, peraturan yang tetap, yang sebanyak mungkin meniadakan ketidakpastian, jadi makin tepat dan tajam peraturan hukum itu, makin terdesaklah keadilan. Itulah arti summum ius, summa iniuria, keadilan yang tertinggi adalah ketidakadilan yang tertinggi. ${ }^{18}$

Dalam pengertian lain, menurut Satjipto Rahardjo "merumuskan konsep keadilan bagaimana bisa menciptakan keadilan yang didasarkan pada nilai-nilai keseimbangan atas persamaan hak dan kewajiban." Namun harus juga diperhatikan kesesuaian mekanisme yang digunakan oleh hukum, dengan membuat dan mengeluarkan peraturan hukum dan kemudian menerapkan sanksi terhadap para anggota masyarakat berdasarkan peraturan yang telah dibuat itu, perbuatan apa saja yang boleh dan tidak boleh dilakukan yaitu substantif. Namun juga

\footnotetext{
${ }^{17}$ L.J. Van Apeldoorn, (1993), Pengantar Ilmu Hukum, Jakarta: Pradnya Paramita, hlm. 11.

${ }^{18}$ Ibid. hlm.11-13.
} 
harus dikeluarkan peraturan yang mengatur tata cara dan tata tertib untuk melaksanakan peraturan substantif tersebut yaitu bersifat prosedural, misalnya hokum perdata (substantif) berpasangan dengan hukum acara perdata (prosedural). ${ }^{19}$

Lebih lanjut untuk mengukur sebuah keadilan, menurut Fence M. Wantu mengatakan, "adil pada hakekatnya menempatkan sesuatu pada tempatnya dan memberikan kepada siapa saja apa yang menjadi haknya, yang didasarkan pada suatu asas bahwa semua orang sama kedudukannya di muka hukum (equality before the law)." ${ }^{20}$ Oleh karena itu penekanan yang lebih cenderung kepada asas keadilan dapat berarti harus mempertimbangkan hukum yang hidup di masyarakat, yang terdiri dari kebiasaan dan ketentuan hukum yang tidak tertulis. Hakim dalam alasan dan pertimbangan hukumnya harus mampu mengakomodir segala ketentuan yang hidup dalam masyarakat berupa kebiasaan dan ketentuan hukum yang tidak tertulis, manakala memilih asas keadilan sebagai dasar memutus perkara yang dihadapi.

\section{PENUTUP}

\section{Kesimpulan.}

Dari pokok permasalahan yang terdapat dalam penelitian ini, dapat dibuat kesimpulan sebagai berikut:

1. Implikasi yuridis pemecahan perkara yaitu mempercepat dan mempermudah proses pembuktian dalam penyelesaian perkara pidana.

2. Aspek keadilan pengaturan pemecahan berkas perkara (splitsing) pada tahap penuntutan yaitu sebagai kepastian hukum bagi terdakwa dalam mencari keadilan dalam proses penyelesaian perkara pidana.

\section{Saran.}

1. Dalam pemisahan perkara, harus memenuhi syarat sesuai dengan aturan hukum yang berlaku, sehingga tidak ada kesewenang-wenangan dalam pelaksanaan proses penyelesaian perkara pidana.

2. Dalam menyusun surat dakwaan terhadap perkara yang displit sebaiknya jaksa memahami tentang kualitas perkara yang dilakukan pemisahan berkas perkara sehingga tidak bertentangan dengan hak asasi terdakwa dalam memperoleh keadilan.

\footnotetext{
${ }^{19}$ Satjipto Rahardjo, Op. Cit., hlm.77-78.

${ }^{20}$ Fence M. Wantu, (2012), "Mewujukan Kepastian Hukum, Keadilan dan Kemanfaatan Dalam Putusan HLMakim di Peradilan Perdata", Jurnal Dinamika Hukum, Volume 12 Nomor 3, hlm.484.
} 


\section{DAFTAR PUSTAKA}

\section{Buku}

Andi Hamzah dan RM. Surachman, (2014), Hukum Acara Pidana Indonesia, Jakarta: Sinar Grafika.

Andi Hamzah, (2014), Hukum Acara Pidana Indonesia, Jakarta: Sinar Grafika.

Bismar Siregar, (1983), Hukum Acara Pidana, Jakarta: Bina Cipta.

Fadli Satrianto, (2015), Pemisahan Berkas Perkara (Splitsing) Dalam Perkara Pidana Ditinjau Dari Hukum Positif, Universitas Airlangga.

Hari Sasangka dan Lily Rosita, (2003), Hukum Pembuktian dalam Perkara Pidana, Bandung: Mandar Maju.

L.J. Van Apeldoorn, (1993), Pengantar Ilmu Hukum, Jakarta: Pradnya Paramita.

Satjipto Rahardjo, (1996), Ilmu Hukum, Bandung: PT. Citra Aditya Bakti.

Wirjono Prodjodikoro dalam Djoko Prakoso. 1988. Pemecahan Perkara Pidana (Splitsing).Yogyakarta: Liberty

Yahya Harahap, (2000), Pembahasan Permasalahan dan Penerapan KUHAP Penyidikan dan Penuntutan. Edisi Kedua. Jakarta: Sinar Grafika.

--------, (2012), Pembahasan Permasalahan Dan Penerapan KUHAP Penyidikan dan Penuntutan, Jakarta: Sinar Grafika.

\section{Peraturan Perundang-Undangan}

Kitab Undang-Undang Hukum Perdata.

Kitab Undang-Undang Hukum Acara Perdata.

Undang-Undang Nomor 16 Tahun 2004 tentang Kejaksaan.

Undang-Undang Nomor 48 Tahun 2009 tentang Kekuasaan Kehakiman Undang-Undang Nomor 48 Tahun 2009 tentang Kekuasaan Kehakiman.

Putusan Mahkamah Agung Nomor: 1986/K/Pid/1989.

Putusan Mahkamah Agung Republik Indonesia Nomor: 66/K/Kr/1967.

\section{Jurnal}


Cristian Rompas, (2016), "Pemecahan Perkara Pidana (Splitsing) Sebagai Upaya untuk Mempercepat Proses Pembuktian”, Lex Privatum, Volume IV Nomor 2.

Fence M. Wantu, (2012), "Mewujukan Kepastian Hukum, Keadilan dan Kemanfaatan Dalam Putusan HLMakim di Peradilan Perdata", Jurnal Dinamika Hukum, Volume 12 Nomor 3.

Ignasius A. Tiolong, Veibe V.Sumilat, Harold Anis, (2018), "Wewenang Pemecahan Perkara (Splitsing) Oleh Penuntut Umum Menurut Pasal 142 Undang-Undang Nomor 8 Tahun 1981”, Lex Crimen, Volume VII, Nomor 6.

Yati Nurhayati, (2013), "Perdebatan Metode Normatif dengan Metode Empirik Dalam Penelitian Ilmu Hukum Ditinjau Dari Karakter, Fungsi dan Tujuan Ilmu Hukum”, Jurnal Al Adl, Volume 5 Nomor 10.

\section{Internet}

https://123dok.com/document/7q063p9q-kedudukan-sanksi-mahkota-dalam-sistempembuktian-hukum-pidana.html.

http://id.wikipedia.org/wiki/Aristoteles/keadilan. Diakses pada tanggal 10 April 2021.

Kamus Besar Bahasa Indonesia Online, (2020), https://kbbi.web.id/sadap. 